\title{
ニボルマブによる甲状腺機能低下症における好中球/リンパ球比の関与
}

\author{
中澤佑介 ${ }^{* 1}$, 元日田阿子 ${ }^{1}$, 影山 明 $^{1}$, 内海裕文 $^{2}$, 桑野和善 ${ }^{2}$, 川久保孝 \\ 東京慈恵会医科大学附属病院薬剤部 ${ }^{1}$, 東京慈恵会医科大学呼吸器内科 ${ }^{2}$
}

\section{Involvement of Neutrophil-lymphocyte Ratio in Nivolumab Therapy-induced Hypothyroidism}

\author{
Yusuke Nakazawa* ${ }^{* 1}$, Ako Gannichida', Akira Kageyama', \\ Hirofumi Utsumi ${ }^{2}$, Kazuyoshi Kuwano ${ }^{2}$ and Takashi Kawakubo \\ Department of Pharmacy, The Jikei University Hospital ${ }^{1}$, \\ Division of Respiratory Diseases, Department of Internal Medicine, The Jikei University School of Medicine ${ }^{2}$ \\ [ Received April 14, 2020 ) \\ (Accepted July 9, 2020
}

Nivolumab has a period to determine the therapeutic effect, and the first therapeutic effect is evaluated by the sixth dose. Several studies have indicated that the neutrophil-lymphocyte ratio (NLR) is a predictor of efficacy. These studies reported that patients with low levels of NLR had shown favorable therapeutic responses. The continuous administration of levothyroxine may be essential after the development of nivolumab-induced hypothyroidism; therefore, the elucidation of predictors associated with the development of hypothyroidism will be helpful during nivolumab treatment. This study investigated whether the NLR at the sixth dose of nivolumab could be applied as a management index in the patients who received six or more doses of nivolumab to predict the occurrence of hypothyroidism. Of the 90 patients treated with nivolumab, those $(36 \%, \mathrm{n}=47)$ who received six or more doses of nivolumab had a significantly higher incidence of hypothyroidism than those $(9 \%, \mathrm{n}=42)$ who received less than six doses $(P<0.01)$. However, the incidence of hypothyroidism did not increase based on the cumulative dose. Among 47 patients who received nivolumab six or more times, the incidence of hypothyroidism (44\%) in patients with NLR $<5$ was significantly higher than the incidence $(9 \%)$ in patients with NLR $\geq 5(P<0.05)$. The deterioration of thyroid function needs to be monitored because patients with low levels of NLR (less than 5) at the sixth dose are more prone to developing hypothyroidism.

Key words — nivolumab, hypothyroidism, neutrophil-lymphocyte ratio, predictive factor

\section{緒 言}

ニボルマブは, 2014 年に根治切除不能悪性黒 色腫に対する免疫チェックポイント阻害剤として 保険適用され，その後，非小細胞肺がん，腎細胞 がん, 古典的ホジキンリンパ腫, 頭啟部がん, 胃 がん，悪性胸膜中皮腫，結腸・直腸がんおよび食 道がんへの適応拡大が認められ，現在までに多く の担がん患者に使用されている。ニボルマブは優 れた治療成績を示すものの，治療効果を判定する までに期間を有する薬剤であり，投与 6-9 週（投
与回数にして 3-5 回) 後に初回の治療有効性が 評価される. ${ }^{1-7)}$ 薬効が得られないために別の治療 が余儀なくされる場合もあることから, 効果予測 因子の同定は治療を行ううえで大きなニーズの 1 つである. 現在までに, 効果予測因子として好中球 / リンパ球比（neutrophil-lymphocyte ratio: NLR）の 関与が示されており, cut-off 值 : 5 を境界として治 療成績への影響を示す報告が散見される. ${ }^{8-12)}$ ニボ ルマブによる免疫反応の立進は抗腫瘍効果をもた らす一方, 過剰な免疫反応が自己臓器で発現した 際には免疫関連有害事象（immune-related adverse

\footnotetext{
*テ105-8471＼cjkstart東京都港区西新橋3-19-18
} 
events: irAE）を発症する。irAEは，消化管，皮 膚および内分泌器官等の全身の様々な部位に発症 することが知られており, 発症時には適切な対応 が求められる。甲状腺機能低下症の発現頻度は $6.8 \%$ とされているが (オプジーボ®点滴静注添付 文書: 小野薬品工業株式会社, 2020 年 2 月改定, 第 1 版), 不可逆的な副作用であり, 発現後にはレ ボチロキシンの継続的な投与が余儀なくされる. ニボルマブによる治療を行ううえで, 甲状腺機能 低下症の発現に関連する予測因子の探索は治療へ の一助となる. 免疫反応に NLR の值が関連するこ とは，NLRが効果予測だけでなく甲状腺機能低 下症の発現を予期する因子となる可能性があるこ とを意味する。ニボルマブでは 6 回目の投与まで に初回の治療有効性が評価されることから, 本研 究ではニボルマブによる治療開始前の NLR およ び 6 回目投与時におけるNLRについて評価し, NLR が甲状腺機能低下症の発現に関連する因子 となるか検討した。

\section{方 法}

\section{1. 対象患者}

2015 年 1 月〜 2019 年 3 月の間に, 当院にて二 ボルマブが投与された患者を対象に後方視的に調 查を行った．解析対象となる患者の分類を Fig 1 に示す．甲状腺機能低下症および甲状腺がんの既 往のある患者, ニボルマブによる治療開始前の甲 状腺刺激ホルモン（thyroid-stimulating hormone: $\mathrm{TSH}$ ）が基準值の上限以上および遊離サイロキシ ン (free thyroxine: FT4) が基準值の下限未満であっ た患者，TSH およびFT4 が 2 回以上連続して測 定されていない場合には定期的に測定されていな かった患者として対象から除外した，当院におけ る基準值範囲は，TSH が $0.34-4.04 \mu \mathrm{IU} / \mathrm{mL} ， F T 4$ が $0.88-1.67 \mathrm{ng} / \mathrm{dL}$ である.ニボルマブによる全 治療期間中に TSH が基準值上限を 2 度連続して 上回った場合，または FT4 が基準值下限を 2 度 連続して下回った場合を甲状腺機能低下症の発現 と定義した。ニボルマブが 6 回以上抢よび 6 回未 満投与された患者に分類し，ニボルマブが 6 回以 上投与された患者について治療開始前から 6 回目
投与時の臨床検査值の変動を調査した. ニボルマ ブが 6 回未満投与された患者では, 治療の中止理 由が個々に異なること, 治療経過と共に変化する NLR や臨床検査值が不揃いな観察点での採取と なることから，これらの患者デー夕を1つの対象 群として評価できないため, 臨床検查值の変動は ニボルマブが 6 回以上投与された患者において評 価した。ニボルマブは $3 \mathrm{mg} / \mathrm{kg}$ を 2 週間毎に投与 しており，ニボルマブの投与量の改訂に伴い, 当 院では 2018 年 10 月以降にはニボルマブは 240 mg/body で投与した.

\section{2. 調查方法}

ニボルマブが 6 回以上投与された患者について ニボルマブによる治療期間中の甲状腺機能低下症 の発現患者および非発現患者に分類し, 治療開始 前の両患者間における以下の調査項目について比 較した。調査項目は, 性別, 年齢, 体重, がん種, 臨床検査值として TSH, 遊離トリヨードサイロニン (free triiodothyronine: FT3), FT4, 好中球数, リン パ球数, NLR, 血清アルブミン值および $\mathrm{C}$ 反応性 蛋白 (C-reactive protein: CRP) とした. NLRは, [NLR $=$ 好中球数 $(/ \mu \mathrm{L}) /$ リンパ球数 $(/ \mu \mathrm{L})]$ として算 出した. NLRの cut-off 值は先行研究の值 ${ }^{8-12)}$ で ある 5 を採用した。 また, 甲状腺機能低下症の発 現頻度および発現時期を調查し，ニボルマブの累 積投与回数と甲状腺機能低下症の発現時期の相関 を評価した。ニボルマブ 6 回目投与時における臨 床検査值を調查し, 各患者の変動を評価した。甲 状腺機能低下症の発現患者および非発現患者間の 治療開始前からニボルマブ 6 回目投与時における 臨床検査值の変動の比較には, 各值の対数の差を 用いて評価した。

\section{3. 統計解析}

2 群間の量的データの比較には Mann-Whitney’s $U$ test（両側検定）を用い, 質的データの比較には Fisher's exact test（両側検定）を使用した。ニボル マブの累積投与回数と甲状腺機能低下症の発現時 期の相関には Spearman rank correlation coefficient を用いた. 各患者における臨床検査值の変動の比 較には Wilcoxon signed-rank test（両側検定）を用 
いた.すべての統計解析は SAS version 9.4（SAS institute Inc., Cary, NC, USA）を使用した.

\section{4. 倫理規定}

本研究は「人を対象とする医学系研究に関する 倫理指針」を遵守し, 東京慈恵会医科大学倫理委 員会の承認（受付番号：31-048（9547））を得て 実施した。

\section{結＼cjkstart果}

\section{1. 甲状腺機能低下症の発現頻度}

調查期間中にニボルマブが投与された患者は 133 名であった。 甲状腺機能低下症の患者 14 名, 甲状腺がんの患者 3 名, 治療開始前の TSH が基 準值の上限以上㧍よび FT4 が基準值の下限未満 であった患者 22 名，TSH および FT4 が定期的に 測定されていなかった患者 4 名は対象から除外し た。これら除外基準に該当する患者 43 名を除外
した 90 名について調査した（Fig 1)．90 名の患 者のうちニボルマブが 6 回以上拉よび 6 回未満投 与された患者は, それぞれ47名および43名であっ た。ニボルマブが 6 回以上投与された患者では, 甲状腺機能低下症の発現頻度は 36\%（17 / 47 名） であり，6回未満投与された患者の発現頻度 $9 \%$ （4 / 43 名）と比較して有意に高かった $(P<0.01)$ (Table 1).

\section{2. ニボルマブが 6 回以上投与された患者の甲状 腺機能低下症と NLR との関連}

ニボルマブが 6 回以上投与された患者 47 名の うち甲状腺機能低下症の発現患者および非発現患 者は，それぞれ 17 名抒よび 30 名であった。両患 者間のニボルマブによる治療開始前の患者背景に 有意な差は認められなかった（Table 2)。ニボル マブが 6 回以上投与された患者の治療開始前にお ける NLRの平均值は, 甲状腺機能低下症の発現 患者および非発現患者でそれぞれ $2.73 \pm 1.25$ お

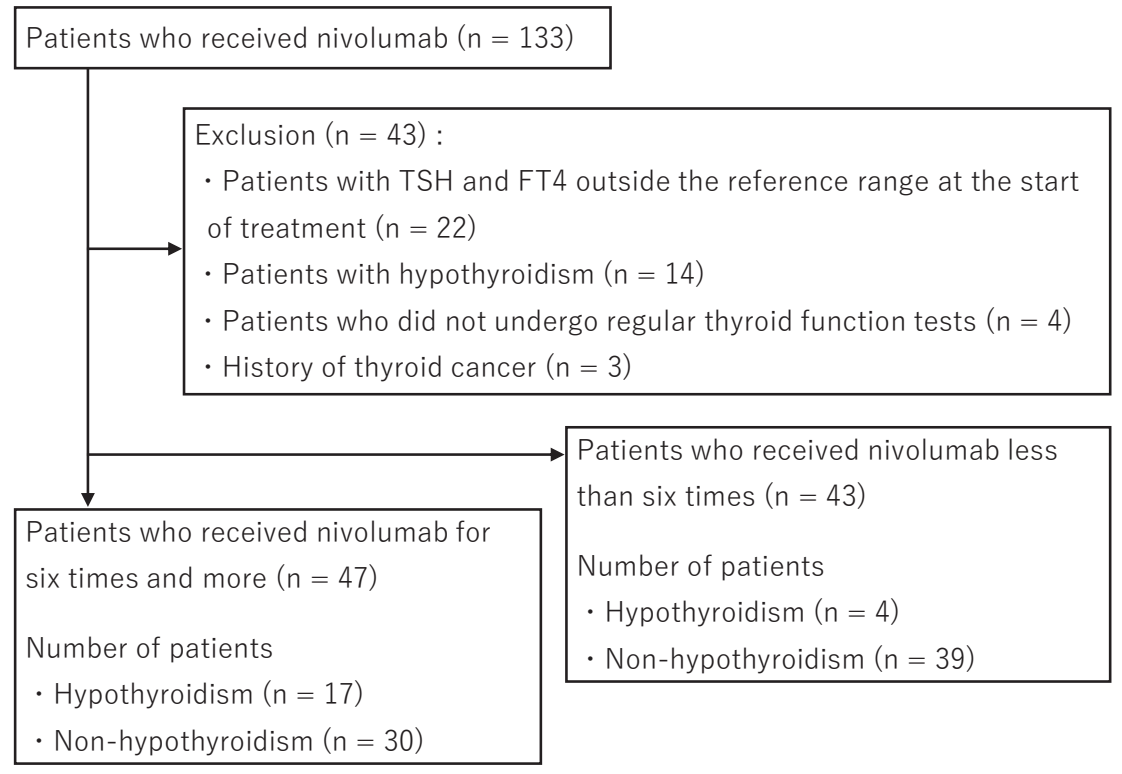

Fig 1 Patients' classification

TSH: thyroid-stimulating hormone, FT4: free thyroxine.

Table 1 Incidence of hypothyroidism in patients received nivolumab

\begin{tabular}{cccc}
\hline \hline Number of doses & Hypothyroidism & Non-hypothyroidism & $P$ value \\
\hline$\geq 6$ doses $(\mathrm{n}=47)$ & 17 & 30 & $<0.01 * *$ \\
$<6$ doses $(\mathrm{n}=43)$ & 4 & 39 & \\
\hline$* * P<0.01$ Fisher's exact test. & & &
\end{tabular}


Table 2 Characteristics of patients

\begin{tabular}{|c|c|c|c|}
\hline & Hypothyroidism $(\mathrm{n}=17)$ & Non-hypothyroidism $(\mathrm{n}=30)$ & $P$ value \\
\hline Median age $(\min -\max )$ & $68(33-86)$ & $69(44-85)$ & $0.54^{\text {a) }}$ \\
\hline Gender (male / female) & $12 / 5$ & $16 / 14$ & $0.36^{b)}$ \\
\hline Body weight $(\mathrm{kg})$ & $59.4 \pm 15.8$ & $51.6 \pm 12.6$ & $0.09^{\text {a) }}$ \\
\hline \multicolumn{4}{|l|}{ Cancer type } \\
\hline Non-small-cell lung cancer & 6 & 14 & \\
\hline Renal cell cancer & 6 & 2 & \\
\hline Head and neck cancer & 3 & 6 & \\
\hline Gastric cancer & 1 & 3 & \\
\hline Malignant melanoma & 1 & 5 & \\
\hline \multicolumn{4}{|l|}{ Laboratory data } \\
\hline $\mathrm{TSH}(\mu \mathrm{IU} / \mathrm{mL})$ & $2.30 \pm 1.10$ & $2.09 \pm 0.84$ & $0.32^{\text {a) }}$ \\
\hline FT4 (ng/dL) & $1.17 \pm 0.24$ & $1.19 \pm 0.20$ & $0.64^{\text {a) }}$ \\
\hline FT3 $(\mathrm{pg} / \mathrm{mL})$ & $2.31 \pm 0.43$ & $2.36 \pm 0.37$ & $0.64^{\text {a) }}$ \\
\hline Serum albumin $(\mathrm{g} / \mathrm{dL})$ & $3.73 \pm 0.62$ & $3.59 \pm 0.43$ & $0.18^{\text {a) }}$ \\
\hline C-reactive protein (mg/dL) & $0.51 \pm 0.77$ & $1.08 \pm 1.43$ & $0.27^{\text {a) }}$ \\
\hline Neutrophil count $(/ \mu \mathrm{L})$ & $3,318 \pm 1,331$ & $4,563 \pm 2,494$ & $0.08^{\text {a) }}$ \\
\hline Lymphocyte count $(/ \mu \mathrm{L})$ & $1,394 \pm 581$ & $1,570 \pm 620$ & $0.27^{\text {a) }}$ \\
\hline NLR & $2.73 \pm 1.25$ & $3.28 \pm 1.96$ & $0.55^{\text {a) }}$ \\
\hline NLR $<5$ & 12 & 16 & 26 b) \\
\hline $\mathrm{NLR} \geq 5$ & 5 & 14 & 0.36 \\
\hline
\end{tabular}

a) Mann-Whitney $U$-test, b) Fisher's exact test. TSH: thyroid-stimulating hormone, FT4: free thyroxine, FT3: free triiodothyronine, NLR: neutrophil-lymphocyte ratio.

よび $3.28 \pm 1.96$ であり，両患者間の NLR に有意 差は認められなかった $(P=0.55)$ ，治療開始前の NLR が 5 未満の患者における甲状腺機能低下症の 発現頻度は, NLR が 5 以上の患者の発現頻度と比 較して有意差は認められなかった $(P=0.36)$.甲 状腺機能低下症の発現患者および非発現患者にお けるニボルマブの累積投与回数中央值（最小值 最大值）は，それぞれ 20（7-65）回および 14（6 - 60）回であり，投与期間中における甲状腺機能 低下症の発現時期中央值 (最小值 - 最大值) は 7 (3 - 36）回であった。ニボルマブの累積投与回数と 甲状腺機能低下症の発現時期の相関を観察したと ころ, 累積投与回数と甲状腺機能低下症の発現時 期に有意な相関は認められなかった $(r=0.356$, $P=0.16 ） （$ Fig 2)．ニボルマブが 6 回以上投与さ れた患者の治療開始前から 6 回目投与時の臨床検 査值の変動を Table 3 に示す。状腺機能低下症 の発現患者における治療開始前から 6 回目投与時 の NLR の平均值は, $2.73 \pm 1.25$ から $2.76 \pm 1.20$ であり，有意な変動は認められなかった（ $P=$ 0.83). 甲状腺機能低下症の非発現患者において 治療開始前から 6 回目投与時のリンパ球数の平均 值は, $1,570 \pm 620 / \mu \mathrm{L}$ から $1,377 \pm 536 / \mu \mathrm{L}$ へ有

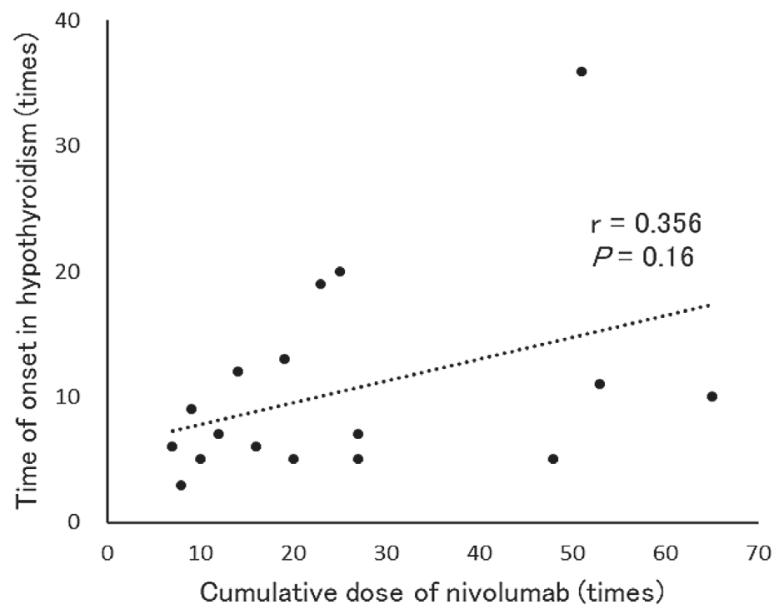

Fig 2 The time of onset in nivolumab-induced hypothyroidism

The correlation was analyzed by Spearman rank correlation coefficient.

意な低下が認められており $(P=0.037), N L R の$ 平均值は $3.28 \pm 1.96$ から $3.68 \pm 2.55$ へ有意な上 昇が認められた $(P=0.035)$. 各臨床検査值の治 療開始前から 6 回目投与時の対数変動率には, 両 患者間で有意差は認められなかった。なお，治療 期間中に感染症を起こした患者はいなかった。二 ボルマブ 6 回目投与時の NLR が 5 未満の患者に 
Table 3 Outcome in the sixth dose of nivolumab

\begin{tabular}{|c|c|c|c|c|c|c|}
\hline & Hypothyroidism & Before treatment & At the sixth dose & $P$ value & Fluctuation & $P$ value \\
\hline \multirow{2}{*}{$\begin{array}{l}\text { Neutrophil count } \\
(/ \mu \mathrm{L})\end{array}$} & developed & $3,318 \pm 1,331$ & $3,376 \pm 1,129$ & $0.96^{\text {a) }}$ & $0.017 \pm 0.178$ & \multirow{2}{*}{$0.76^{\mathrm{b})}$} \\
\hline & non-developed & $4,563 \pm 2,494$ & $4,227 \pm 2,089$ & $0.91^{\text {a) }}$ & $-0.024 \pm 0.200$ & \\
\hline \multirow{2}{*}{$\begin{array}{l}\text { Lymphocyte count } \\
(/ \mu \mathrm{L})\end{array}$} & developed & $1,394 \pm 581$ & $1,382 \pm 514$ & $0.98^{\text {a) }}$ & $0.008 \pm 0.102$ & \multirow{2}{*}{$0.08^{\mathrm{b})}$} \\
\hline & non-developed & $1,570 \pm 620$ & $1,377 \pm 536$ & $0.037 *$ a) & $-0.058 \pm 0.157$ & \\
\hline \multirow{2}{*}{ NLR } & developed & $2.73 \pm 1.25$ & $2.76 \pm 1.20$ & $0.83^{\text {a) }}$ & $0.009 \pm 0.144$ & \multirow{2}{*}{$0.54^{\mathrm{b})}$} \\
\hline & non-developed & $3.28 \pm 1.96$ & $3.68 \pm 2.55$ & $0.035 *$ a) & $0.035 \pm 0.115$ & \\
\hline \multirow{2}{*}{$\begin{array}{l}\text { Serum albumin } \\
(\mathrm{g} / \mathrm{dL})\end{array}$} & developed & $3.73 \pm 0.62$ & $3.91 \pm 0.45$ & $0.16^{\mathrm{a})}$ & $0.024 \pm 0.063$ & \multirow{2}{*}{$0.37^{b)}$} \\
\hline & non-developed & $3.59 \pm 0.43$ & $3.59 \pm 0.50$ & $0.91^{\text {a) }}$ & $-0.001 \pm 0.045$ & \\
\hline \multirow{2}{*}{$\begin{array}{l}\text { C-reactive protein } \\
(\mathrm{mg} / \mathrm{dL})\end{array}$} & developed & $0.51 \pm 0.77$ & $0.72 \pm 0.74$ & $0.16^{\text {a) }}$ & $0.255 \pm 0.524$ & \multirow{2}{*}{$0.24^{\mathrm{b})}$} \\
\hline & non-developed & $1.08 \pm 1.43$ & $1.36 \pm 2.63$ & $0.82^{a)}$ & $-0.071 \pm 0.688$ & \\
\hline
\end{tabular}

$* P<0.05$. a) Wilcoxon signed-rank test, b) Mann-Whitney $U$-test.

Table 4 Incidence of hypothyroidism with neutrophil-lymphocyte ratio less than 5

\begin{tabular}{lccc}
\hline \hline & Hypothyroidism $(\mathrm{n}=17)$ & Non-hypothyroidism $(\mathrm{n}=30)$ & $P$ value \\
\hline $\mathrm{NLR}<5$ & 16 & 20 & \multirow{2}{*}{$0.039^{*}$} \\
$\mathrm{NLR} \geq 5$ & 1 & 10 & \\
\hline
\end{tabular}

$* P<0.05$ Fisher's exact test. NLR: neutrophil-lymphocyte ratio.

おける甲状腺機能低下症の発現頻度は 44\%（16/ 36 名)であり, NLR が 5 以上の患者の発現頻度 $9 \%$ （1／11 名）と比較して有意に高かった $(P=0.039)$ ( Table 4).

\section{考察}

本研究で観察点として設定したニボルマブ 6 回 目投与時は，ニボルマブの治療有効性を初回に評 価する時期であるが，一方で甲状腺機能低下症の 発現時期は, $7.4-16.0$ 週 (投与回数にして 5-9回) とされ ${ }^{1-7)} 6$ 回目投与時は好発時期の初期に相当 する. 本研究でも甲状腺機能低下症を発現した患 者にはニボルマブの投与 6 回目以降だけでなく, それ以前に甲状腺機能低下症を発現した患者も含 まれている。しかしながら，患者の多くが投与 6 回目以降に甲状腺機能低下症を発現していること から（Table 1），6 回目投与時という観察点およ び 6 回以上投与された患者における NLR の評価 は，治療効果の予測だけでなく甲状腺機能低下症 の発現を予測するためにも有用な時期となる可能 性が考えられた。一方で，観察期間の長さにより 甲状腺機能低下症の発現頻度が増加することが考 えられるが，二ボルマブの累積投与回数と甲状腺
機能低下症の発現時期の相関を観察したところ， 累積投与回数と甲状腺機能低下症の発現時期に有 意な相関は認められなかった (Fig 2). 甲状腺機 能低下症は治療後期にも発現するが，多くは治療 初期に発現し，累積投与回数に依存しないことか ら, 治療期間の延長が甲状腺機能低下症の発現頻 度に関連する可能性は低いと考えられた。すなわ ち, 甲状腺機能低下症は長期の薬物嚗露でも累積 毒性を認めにくい副作用であると考えられる.

過去の研究では, 良好な治療予後を認めた患者 では治療開始時の NLR は低值を示すこと ${ }^{8-13)} や$ 治療有効性を示す患者では治療期間の長さと共に NLRが低下すること ${ }^{14,15}$ が報告されている.また， ニボルマブによる良好な治療成績には甲状腺機能 障害の発現の関与を示す報告がある. ${ }^{16,17)}$ しかし ながら, 治療有効性を示す患者の NLR 低值が, 甲状腺機能低下症の発現頻度の増加を導くとした 結論にはこれらの報告からは至っていない。NLR は一定の值を下回る場合, 良好な治療成績との関 連が示されており，その cut-off 值を 5 と設定し

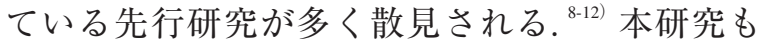
cut-off 值 5 を用いることで, 同じ評価基準から甲 状腺機能低下症の発現への評価に応用できるか検 討した。本研究ではニボルマブが 6 回以上投与さ 
れた一定以上の治療有効性を示す患者のみを対象 としているため, 過去の報告 ${ }^{8-15)}$ と同様に, 治療 開始前およびニボルマブ 6 回目投与時の NLR は 低值を示していた。甲状腺機能低下症の発現患者 では, 治療開始前とニボルマブ 6 回目投与時を比 較して NLR の有意な変動は認められなかったが, 非発現患者ではNLRの有意な上昇が認められた。 NLR は好中球数とリンパ球数から算出され, 好 中球数の変動には感染症の影響が考慮されるが治 療期間中に感染症を起こした患者はおらず，CRP 值にも有意な変動は認められなかった。また，リ ンパ球数の変動には栄養状態の影響が考慮される が血清アルブミン值に有意な変動は認められない ことから, 患者の背景因子による影響は小さいと 考えられた（Table 3).

活性化 $\mathrm{T}$ 細胞上に発現している PD-1 が，がん 細胞に発現したPD-L1 と結合することにより T 細胞への抑制シグナルが送られるが，ニボルマブ はこの抑制シグナルを抑制することにより T 細 胞の活性化を促している. ${ }^{18)}$ また, ニボルマブで はリンパ球やマクロファージが活性化し, 血球が 領食されることにより起こる血球領食症候群や無 顆粒球症の副作用も報告されている. ${ }^{19,20)} こ の$ 機 序ゆえにニボルマブによる T 細胞の再活性化は, 抗腫瘍効果に関連し NLRの低下を示すと考えら れる，一方で，ニボルマブによる抗腫瘍免疫と抗 甲状腺免疫とに関連するメカニズムについては, 現時点において明らかにされていないが, ニボル マブによる免疫担当細胞の活性化は, 腫瘍細胞に 対する抗腫瘍効果を示す一方, 自己宽容の崩壊に 伴い, 甲状腺の自己免疫関連反応による甲状腺機 能低下症を引き起こすと考えられる. 本研究では, NLR が低值を示す患者の中でも, 特にニボルマ ブ 6 回目投与時の NLR が 5 未満の患者では甲状 腺機能低下症の発現頻度が有意に高いとの結果が 得られた。すなわち，ニボルマブによる免疫反応 充進に伴うNLR 低值は, 抗腫瘍効果だけでなく 甲状腺機能低下症の発現にも関連を示す可能性が 示唆され, 注意深い甲状腺機能検查值のモニタリ

ングが必要となると考えられた。

本研究の甲状腺機能低下症の発現率は, 臨床試 験の報告值 $(3.0-7.6 \%)^{1-7)}$ よりも高值を示してい
た. CTCAE（有害事象共通用語規準 v4.0 日本語 訳 JCOG 版）による甲状腺機能低下症の発現定義 には, 甲状腺機能検査值の変動だけでなく臨床症 状や治療の必要性も加味されるが, 臨床症状は評 価者の主観的な判断に基づくことから, CTCAE の定義では甲状腺機能低下症の評価にばらつきが 生じる可能性が考えられる. 本研究では甲状腺機 能低下症の発現定義を TSH および FT4 の変動と する客観的指標を用いた評価により，ニボルマブ の治療に抢いて特にNLR 低值患者に対して甲状 腺機能検查值のモニタリングの必要性が高いこと を示唆した。しかしながら, 本研究はがん種を特 定としない単施設での解析であり, がん種別や大 きなコホートに扔ける検討も必要と考えられる。

現在, 甲状腺機能低下症の発現に関連する因子 として, 抗甲状腺ペルオキシダーゼ抗体あるいは 抗サイログロブリン抗体の関与が指摘されている が, ${ }^{21)}$ 日常診療において定期的に測定される検査 項目ではない. 一方, 好中球数およびリンパ球数 は副作用の評価や治療効果予測をするうえで常々 測定される。本研究により，ニボルマブ投与時の NLRの評価は治療効果の予測だけでなく, 甲状 腺機能低下症の発現を予測する管理指標としても 応用できる可能性が示唆された。

\section{利益相反}

桑野和善 (小野薬品工業株式会社, アステラス 製薬株式会社, 杏林製薬株式会社, 日本ベーリン ガーインゲルハイム株式会社).

\section{引用文献}

1) Brahmer J, Reckamp KL, Baas P, Crinò L, Eberhardt WE, Poddubskaya E, Antonia S, Pluzanski A, Vokes EE, Holgado E, Waterhouse D, Ready N, Gainor J, Arén Frontera O, Havel L, Steins M, Garassino MC, Aerts JG, Domine M, Paz-Ares L, Reck M, Baudelet C, Harbison CT, Lestini B, Spigel DR, Nivolumab versus Docetaxel in Advanced Squamous-Cell Non-Small-Cell Lung Cancer, N Engl J Med, 2015, 373, 123-135.

2) Borghaei H, Paz-Ares L, Horn L, Spigel DR, Steins 
M, Ready NE, Chow LQ, Vokes EE, Felip E, Holgado E, Barlesi F, Kohlhäufl M, Arrieta O, Burgio MA, Fayette J, Lena H, Poddubskaya E, Gerber DE, Gettinger SN, Rudin CM, Rizvi N, Crinò L, Blumenschein GR Jr, Antonia SJ, Dorange C, Harbison CT, Graf Finckenstein F, Brahmer JR, Nivolumab versus Docetaxel in Advanced Nonsquamous Non-Small-Cell Lung Cancer, $N$ Engl J Med, 2015, 373, 1627-1639.

3) Motzer RJ, Escudier B, McDermott DF, George S, Hammers HJ, Srinivas S, Tykodi SS, Sosman JA, Procopio G, Plimack ER, Castellano D, Choueiri TK, Gurney H, Donskov F, Bono P, Wagstaff J, Gauler TC, Ueda T, Tomita Y, Schutz FA, Kollmannsberger C, Larkin J, Ravaud A, Simon JS, Xu LA, Waxman IM, Sharma P; CheckMate 025 Investigators, Nivolumab versus Everolimus in Advanced Renal-Cell Carcinoma, $N$ Engl J Med, 2015, 373, 1803-1813.

4) Weber JS, D’Angelo SP, Minor D, Hodi FS, Gutzmer R, Neyns B, Hoeller C, Khushalani NI, Miller WH Jr, Lao CD, Linette GP, Thomas L, Lorigan P, Grossmann KF, Hassel JC, Maio M, Sznol M, Ascierto PA, Mohr P, Chmielowski B, Bryce A, Svane IM, Grob JJ, Krackhardt AM, Horak C, Lambert A, Yang AS, Larkin J, Nivolumab versus chemotherapy in patients with advanced melanoma who progressed after anti-CTLA-4 treatment (CheckMate 0379: a randomised, controlled, open-label, phase 3 trial, Lancet Oncol, 2015, 16, 375-384.

5) Robert C, Long GV, Brady B, Dutriaux C, Maio M, Mortier L, Hassel JC, Rutkowski P, McNeil C, Kalinka-Warzocha E, Savage KJ, Hernberg MM, Lebbé C, Charles J, Mihalcioiu C, Chiarion-Sileni V, Mauch C, Cognetti F, Arance A, Schmidt H, Schadendorf D, Gogas H, Lundgren-Eriksson L, Horak C, Sharkey B, Waxman IM, Atkinson V, Ascierto PA, Nivolumab in previously untreated melanoma without BRAF mutation, $N$ Engl J Med, 2015, 372, 320-330.

6) Ferris RL, Blumenschein G Jr, Fayette J, Guigay J, Colevas AD, Licitra L, Harrington K, Kasper S, Vokes EE, Even C, Worden F, Saba NF, Iglesias Docampo LC, Haddad R, Rordorf T, Kiyota N, Tahara M, Monga M, Lynch M, Geese WJ, Kopit J, Shaw JW, Gillison ML, Nivolumab for Recurrent
Squamous-Cell Carcinoma of the Head and Neck, $N$ Engl J Med, 2016, 375, 1856-1867.

7) Kang YK, Boku N, Satoh T, Ryu MH, Chao Y, Kato K, Chung HC, Chen JS, Muro K, Kang WK, Yeh KH, Yoshikawa T, Oh SC, Bai LY, Tamura T, Lee KW, Hamamoto Y, Kim JG, Chin K, Oh DY, Minashi K, Cho JY, Tsuda M, Chen LT, Nivolumab in patients with advanced gastric or gastro-oesophageal junction cancer refractory to, or intolerant of, at least two previous chemotherapy regimens (ONO-453812, ATTRACTION-2): a randomised, double-blind, placebo-controlled, phase 3 trial, Lancet, 2017, 390, 2461-2471.

8) Ueda T, Chikuie N, Takumida M, Furuie H, Kono T, Taruya T, Hamamoto T, Hattori M, Ishino T, Takeno $\mathrm{S}$, Baseline neutrophil-to-lymphocyte ratio (NLR) is associated with clinical outcome in recurrent or metastatic head and neck cancer patients treated with nivolumab, Acta Otolaryngol, 2020, 140, 181187.

9) Bagley SJ, Kothari S, Aggarwal C, Bauml JM, Alley EW, Evans TL, Kosteva JA, Ciunci CA, Gabriel PE, Thompson JC, Stonehouse-Lee S, Sherry VE, Gilbert E, Eaby-Sandy B, Mutale F, DiLullo G, Cohen RB, Vachani A, Langer CJ, Pretreatment neutrophil-to-lymphocyte ratio as a marker of outcomes in nivolumab-treated patients with advanced non-small-cell lung cancer, Lung Cancer, 2017, 106, 1-7.

10) Kao SC, Pavlakis N, Harvie R, Vardy JL, Boyer MJ, van Zandwijk N, Clarke SJ, High blood neutrophil-to-lymphocyte ratio is an indicator of poor prognosis in malignant mesothelioma patients undergoing systemic therapy, Clin Cancer Res, 2010, 16, 5805-5813.

11) Ogata $T$, Satake H, Ogata M, Hatachi Y, Inoue K, Hamada M, Yasui H, Neutrophil-to-lymphocyte ratio as a predictive or prognostic factor for gastric cancer treated with nivolumab: a multicenter retrospective study, Oncotarget, 2018, 9, 34520-34527.

12) Park W, Kwon D, Saravia D, Desai A, Vargas F, El Dinali M, Warsch J, Elias R, Chae YK, Kim DW, Warsch S, Ishkanian A, Ikpeazu C, Mudad R, Lopes G, Jahanzeb M, Developing a Predictive Model for Clinical Outcomes of Advanced Non-Small Cell Lung Cancer Patients Treated With Nivolumab, Clin Lung Cancer, 2018, 19, 280-288. 
13) Chua TC, Chong CH, Liauw W, Zhao J, Morris DL, Inflammatory markers in blood and serum tumor markers predict survival in patients with epithelial appendiceal neoplasms undergoing surgical cytoreduction and intraperitoneal chemotherapy, Ann Surg, 2012, 256, 342-349.

14）梅原健吾, 山 佳織, 後藤佳輔, 岡崎泰香, 若本 あずさ,初山多恵, 本庄 統, 佐藤秀紀, 非小細胞 肺癌患者におけるニボルマブの効果予測因子の 検討, 日本臨床腫瘍薬学会雑誌, 2019, 11, 13-21.

15) Ameratunga $M$, Chénard-Poirier $M$, Moreno Candilejo I, Pedregal M, Lui A, Dolling D, Aversa C, Ingles Garces A, Ang JE, Banerji U, Kaye S, Gan H, Doger B, Moreno V, de Bono J, Lopez J, Neutrophil-lymphocyte ratio kinetics in patients with advanced solid tumours on phase I trials of PD-1/PD-L1 inhibitors, Eur J Cancer, 2018, 89, 5663.

16) Osorio JC, Ni A, Chaft JE, Pollina R, Kasler MK, Stephens D, Rodriguez C, Cambridge L, Rizvi H, Wolchok JD, Merghoub T, Rudin CM, Fish S, Hellmann MD, Antibody-mediated thyroid dysfunction during T-cell checkpoint blockade in patients with non-small-cell lung cancer, Ann Oncol, 2017, 28, 583-589.

17) Yamauchi I, Yasoda A, Matsumoto S, Sakamori Y, Kim YH, Nomura M, Otsuka A, Yamasaki T, Saito R, Kitamura M, Kitawaki T, Hishizawa M, Kawaguchi-Sakita N, Fujii T, Taura D, Sone M, Inagaki N, Incidence, features, and prognosis of immune-related adverse events involving the thyroid gland induced by nivolumab, PLoS One, 2019, 14, e0216954. doi : 10.1371/journal.pone.0216954.

18) Wang C, Thudium KB, Han M, Wang XT, Huang H, Feingersh D, Garcia C, Wu Y, Kuhne M, Srinivasan M, Singh S, Wong S, Garner N, Leblanc H, Bunch RT, Blanset D, Selby MJ, Korman AJ, In vitro characterization of the anti-PD-1 antibody nivolumab, BMS-936558, and in vivo toxicology in non-human primates, Cancer Immunol Res, 2014, 2, 846-856.

19) Hantel A, Gabster B, Cheng JX, Golomb H, Gajewski TF, Severe hemophagocytic lymphohistiocytosis in a melanoma patient treated with ipilimumab + nivolumab, J Immunother Cancer, 2018, 6, 73. doi : 10.1186/s40425-018-0384-0.

20) Tokumo K, Masuda T, Miyama T, Miura S, Yamaguchi K, Sakamoto S, Horimasu Y, Nakashima T, Miyamoto S, Yoshida T, Iwamoto H, Fujitaka K, Hamada H, Hattori N, Nivolumab-induced severe pancytopenia in a patient with lung adenocarcinoma, Lung Cancer, 2018, 119, 21-24.

21) Kobayashi T, Iwama S, Yasuda Y, Okada N, Tsunekawa T, Onoue T, Takagi H, Hagiwara D, Ito Y, Morishita Y, Goto M, Suga H, Banno R, Yokota K, Hase T, Morise M, Hashimoto N, Ando M, Kiyoi H, Gotoh M, Ando Y, Akiyama M, Hasegawa Y, Arima H, Patients With Antithyroid Antibodies Are Prone To Develop Destructive Thyroiditis by Nivolumab: A Prospective Study, J Endocr Soc, 2018, 2, 241251. 